\title{
EFFECTS OF CALCIUM CHANNELBLOCKER VERAPAMIL ON BONE AND DENTAL GERM IN RATS
}

\section{MARIA DAS GRACAS VILELA-GOULART ${ }^{1}$; WILMA P. BASTOS-RAMOS ${ }^{\mathbf{1}}$; ROSILENE FERNANDES DA ROCHA ${ }^{2}$; MIGUEL ANGEL C. SALGADO ${ }^{1}$; JOSÉ RANALI ${ }^{3}$}

\author{
${ }^{1}$ Departamento de Ciências Básicas; ${ }^{2}$ Departemento de Patologia - Faculdade de Odontologia - UNESP - São \\ José dos Campos-SP; ${ }^{3}$ Departamento de Farmacologia, Anestesiologia e Terapêutica Medicamentosa - \\ Faculdade de Odontologia - UNICAMP - Piracicaba - SP - Brasil.
}

\begin{abstract}
Verapamil and other calcium blocker drugs are used as antihypertensive and antiarrhythmic in long term treatments and appropriate to be prescribed for pregnant women. It was studied in rats the effects of verapamil on dental germ calcification, the time of dental eruption in offspring born from treated mothers and on mother's bone mineralization. The rats were divided in two groups: one received verapamil in doses of $2.4 \mathrm{mg} / \mathrm{rat} / \mathrm{day}$ and the other, $24 \mathrm{mg} / \mathrm{rat} / \mathrm{day}$. The animals were divided in two subgroups: one was treated during 10 weeks: 7 before mating and 3 during pregnancy, cesarean surgery performed on the $21^{\text {st }}$ day; the other was treated in the same way but the offspring were born by natural delivery and the mothers' treatment continued for 15 days. Plasma calcium and phosphate were assayed in mothers and offspring. The offspring's heads were isolated to histology of dental germs and determined mothers' femoral bone fresh and dry weights. Results show that the higher dose verapamil lowered mother's plasmatic calcium and phosphate while a significant lower values were observed in offspring as compared to their mothers. Verapamil increased mothers' femoral bone mineralization during mineralization but not after delivery. An increased calcium deposition of dental germ could not be demonstrated but verapamil significantly delayed newborn's dental eruption.
\end{abstract}

RESUMO - O verapamil e outros bloqueadores dos canais de cálcio são usados como antihipertensivos e antiarrítmicos tratamentos prolongados ou por toda a vida, podendo ser indicados em gestantes. Foi estudado o efeito do bloqueador dos canais de cálcio sobre o germe dental, tempo de erupção dentária de filhotes nascidos de mães tratadas e mineralização óssea nas mães. As fêmeas tratadas foram divididas em dois grupos: o primeiro recebeu verapamil na dose de $2,4 \mathrm{mg} / \mathrm{rato} / \mathrm{dia}$ e o segundo, $24 \mathrm{mg} / \mathrm{rato} / \mathrm{dia}$. Os animais foram divididas em dois subgrupos: o primeiro recebeu a droga durante 10 semanas: 7 semanas antes do acasalamento e 3 semanas durante a gestação realizando-se a operação cesariana ao $21^{\circ}$ dia; o outro foi tratado como o primeiro, porem os filhotes nasceram de parto natural e o tratamento das mães foi continuado por 15 dias. Foram determinados os níveis plasmáticos de cálcio e fosfato de mães e filhotes. As cabeças dos filhotes foram seccionadas para histologia dos germes dentários e determinados os pesos úmido e seco do osso femoral das mães. Os resultados mostraram que a droga, na dose mais elevada, diminuiu os níveis séricos de cálcio e fosfato nas mães, enquanto que nos filhotes, os valores foram significativamente mais baixos em comparação com as mães. $\mathrm{O}$ verapamil causou aumento da mineralização óssea nas mães durante a gestação, mas não após o parto. Um aumento da calcificação dos germes dentários dos filhotes não pôde ser demonstrada, porem na dose mais elevada, o verapamil causou retardo significativo na erupção dentária.

\section{Introduction}

Verapamil, a phenylalkylamine, was the first calcium blocking channel to be clinically useful as antiarrhymic and antihypertensive and in angina pectoris, being still widely used nowadays. The drug acts by preventing ionized calcium from entering the cell and thus influencing calcium dependent processes (FLECKENSTEIN et al., 1967, 1969). It is proposed to act on slow voltage dependent calcium channels of the L type (NOWICKY et

Correspondence should be addressed to: Wilma P. BastosRamos. Faculdade de Odontologia-UNESP. Rua Francisco José Longo, 777 - CEP 12.245-000 - S. José dos Campos, S. Paulo. Tel. (012) 321-81-66, R.1201. Fax (011) 3667-6892. E-mail: wilmabastos@uol.com.br. al., 1985) of excitable cells. An interest arises whether calcium channel blockers influence the calcium balance in bone tissues or not. The occurrence of calcium receptors of the L type channels in the rat osteoblasts was proposed by GRYGORCZYK et al. (1989) and calcium receptors and/or calcium channels were suggested to occur in the osteoclasts (DATTA et al., 1990; ZAIDI et al., 1989, 1990; RITCHIE et al., 1994). In in vitro experiments, HERMANNERLEE et al. (1977) demonstrated that verapamil inhibited parathormone-stimulated release of calcium from bone and LERNER and GUSTAFSON (1982) described its inhibitory effect on ${ }^{45} \mathrm{Ca}$ release from bone in tissue culture. SIMEKOVA et al.(1987) found that verapamil enhanced bone calcium and phosphate 
concentration in rat, suggesting that such action could be due to the inhibition of parathormone followed by inhibition of the osteoclasts function and preponderance of anabolic processes in the bone. In accordance, CHAGNAC et al. (1989) showed that verapamil inhibited parathormoneinduced bone reabsorption in uremic rats. SAMNEGARD and SJÖDÉN (1992), in long term treatments of male and female rats with verapamil, found that the drug increased bone volume and osteopenia in female displaying however an opposite effect in male rats; they argue that the drug could be act upon sexual hormones indirectly inducing osteoporosis in the female and stimulating androgen hormones in males. Calcium channels blocking dihidropyridines (RITCHIE et al., 1994) are supposed to bind osteoclasts in cell culture, increasing intracellular calcium. FOX and DELLA-SANTINA (1989) reported in rats an increase in bone mineralization by verapamil. However, DURRIEZ et al. (1990) reported that verapamil appeared to reduce the amount of heterotropic bone formation in response to tenotomy in rats. Moreover, AMORIM (1995) described that blocking calcium channels isradipine did not influence alveolar reparative process in wound due to dental excision.

Considering that: a) according several authors verapamil exerts some influence on bone mineralization and development; b) the drug can be administered to pregnant women and c) no data is referred about a possible repercussion on children's dental calcification or eruption, we decided to carry out a preliminary study in rats, about the effects of verapamil in long term treatments of pregnant mothers, on the newborn dental germ mineralization and germination and, as a side control, on mothers' bone mineralization.

\section{Material and Methods}

For the experiments, 60 Wistar rats in controlled good health conditions were used. Forty-one were virgin females, aged 90-100 days at the onset of the experiments and 19 were reproductive male rats. The female were divided into two groups according the doses of verapamil administered: $2.4 \mathrm{mg} / \mathrm{rat} /$ day ("low dose"- D1) and $24 \mathrm{mg} / \mathrm{rat} /$ day ("high dose"D2). The rats were divided in two subgroups: to the first, verapamil was administered during 7 weeks before mating and 3 weeks during pregnancy; the second was treated the same way but the administration of the drug continued for 15 days after natural delivery. The drug was mixed to the drinking water added with sucrose $(0.5 \mathrm{~g} / \mathrm{rat} / \mathrm{day})$. Control groups of no treated rats were run in parallel. All the animals were weekly weighed. After the initial seven weeks of treatment it was determined the estrous phase, when female and male were put together overnight for mating. Diagnosis of pregnancy was determined by the presence of spermatozoa in the vaginal secretion (see NICHOLAS, 1949). At cesarean surgery or 15 days after natural delivery, heparinized blood samples were taken from mothers and young and the animals were sacrificed. Mother's femoral bone was removed and freed of adherent soft tissues; length, fresh and dry weights $\left(120^{\circ} \mathrm{C} / 24\right.$ they hours) were assayed. The dry weight was considered as mineralization index, as used by SAMNEGARD and SJÖDÉN (1992). For microscopic histochemical studies, the heads were excised, fixed in $10 \%$ formaldehyde for 24 hours, cut at medial sagital plane, hydrated, dehydrated, diaphanized, prepared in paraffin and dyed for microscopy according Von KOSSA histochemical method (PEARSE, 1972). The dental germ tissue was examined by optical microscopy with 100 and 200x magnification. It was observed pulp cells, alveolar tissue and dental germ. Dental germination period was observed along 15 days in offspring born from natural delivery. Assays of calcium and inorganic phosphate were carried out in plasma obtained from mothers and newborn rats, using a Beckman-Du 600 Spectrophotometer. Plasma calcium was determined by compleximetric method of o-cresolphtalein-complexon using Merck Reagents. For plasmatic inorganic phosphate assay FISKE and SUBAROW (1925) method was used.

Mathematical-statistical processing: significance of the difference between groups was assessed by non-parametric variance analysis of Kruskal Wallis. A multiple comparison among groups was carried out using the GMC computer program version 7.0, according CONOVER (1980).

\section{Results}

Femoral bone fresh and dry weights. Fresh and dry weights of mothers' femoral bone were significantly increased in the groups treated with verapamil during 10 weeks, with the lower and higher doses, a result indicating an increased mineralization. In the 12 weeks group, such response was not demonstrated, since fresh and dry femoral bones weight were not increased as compared to control. The bone length was not changed in both groups. The results are in Table 1. 
Calcium Channel Blocker Verapamil and Bone and Dental Germ

Table 1. Femur fresh and dry weight (mg) of mothers from control and verapamil groups in doses of $2.4 \mathrm{mg} / \mathrm{rat} / \mathrm{day}$ (D1) and $24.0 \mathrm{mg} / \mathrm{rat} / \mathrm{day}(\mathrm{D} 2)$, administered during $10^{* *}$ and 12 weeks. $* * *$

\begin{tabular}{l|c|c|c|c|c}
\hline \multicolumn{7}{|c}{10 weeks } & $\begin{array}{c}\text { 12 weeks } \\
(\mathrm{n}=24)\end{array}$ & $\begin{array}{c}\text { Ver. D1 } \\
(\mathrm{n}=18)\end{array}$ & $\begin{array}{c}\text { Ver. D2 } \\
(\mathrm{n}=10)\end{array}$ & $\begin{array}{c}\text { Ver. D1 } \\
(\mathrm{n}=9)\end{array}$ & $\begin{array}{c}\text { Ver. D2 } \\
(\mathrm{n}=10)\end{array}$ \\
\hline Fresh weight & $675( \pm 164)$ & $698( \pm 53.1)^{*}$ & $850( \pm 59.4)^{*}$ & $697( \pm 44.2)$ & $707( \pm 128)$ \\
Dry weight & $306( \pm 32)$ & $345( \pm 6.6)^{*}$ & $353( \pm 21.2)^{*}$ & $320( \pm 15.0)$ & $322( \pm 43.0)$ \\
\hline
\end{tabular}

*significant (increased weight); $* * 7$ weeks before mating and 3 weeks during pregnancy; $* * * 7$ weeks before mating, 3 weeks during pregnancy and 2 weeks after delivery.

Plasmatic calcium and phosphate. In organic plasmatic calcium and phosphate concentration were not changed in mothers treated with the lower dose of verapamil (D1) during 10 weeks. However, their plasmatic content were significantly decreased with higher dose (D2) in rats treated during 10 weeks as well as with both doses, in those treated along 12 weeks. Regarding to offspring, plasmatic calcium and phosphate were not changed at birth (cesarean). In those born by natural delivery, values were significantly decreased on the $15^{\text {th }}$. day, as compared to control. In every offspring groups, values were significantly lower than the respective mothers. Results are in Table 2.

Table 2. Rats plasmatic calcium $(\mathrm{mg} / 100 \mathrm{ml})$ and phosphate $(\mathrm{mg} / 100 \mathrm{ml})$ from control and verapamil treated groups with doses of $2.4 \mathrm{mg} / \mathrm{rat} /$ day (D1) and $24 \mathrm{mg} / \mathrm{rat} /$ day (D2) during $10^{* * *}$ and $12 * * * *$ weeks. A. - Mothers; B - Offspring.

\begin{tabular}{l|c|c|c|c|c}
\hline A- MOTHERS & 10 weeks & 12 weeks & & \\
\hline & Control & Ver. D1 & Ver. D2 & Ver. D1 & Ver. D2 \\
\hline Calcium & $6.18( \pm 0.27)$ & $5.99( \pm 0.26)$ & $5.47( \pm 0.67)^{*}$ & $5.27( \pm 0.45)^{*}$ & $4.77( \pm 0.44)^{*}$ \\
Phosphate & $3.93( \pm 0.57)$ & $3.90( \pm 0.12)$ & $2.83( \pm 0.71)^{*}$ & $3.08( \pm 0.47)^{*}$ & $2.80( \pm 0.27)^{*}$ \\
\hline
\end{tabular}

\begin{tabular}{l|c|c|c|c|c}
\hline B- OFFSPRING $^{* *}$ & 10 weeks & \multicolumn{4}{l}{} \\
\hline & Control & Ver. D1 & Ver. D2 & Ver. D1 & Ver. D2 \\
\hline Calcium & $5.04( \pm 1.08)$ & $5.21( \pm 0.19)$ & $5.04( \pm 0.15)$ & $4.85( \pm 0.22)^{*}$ & $2.39( \pm 1.56)^{*}$ \\
Phosphate & $2.48( \pm 0.38)$ & $2.41( \pm 0.19)$ & $2.36( \pm 0.93)$ & $2.22( \pm 0.28)^{*}$ & $1.57( \pm 0.60)^{*}$ \\
\hline
\end{tabular}

* significantly lower as compared with respective control mothers or offspring. ** values of calcium and phosphate in offspring significantly lower as compared to their respective mothers. $* * * 7$ weeks before mating and 3 weeks during pregnancy. $* * * * 7$ weeks before mating, 3 weeks during pregnancy and 2 weeks after delivery.

Offspring body weight. As compared to control, a body weight loss in verapamil group related to doses and time of mother's treatment was observed: doses of $2.4 \mathrm{mg} / \mathrm{rat} /$ day for 10 weeks- $7 \%$; for 12 weeks-16\%. Doses of $24 / \mathrm{mg} / \mathrm{rat} /$ day for 10 weeks$20 \%$; for 12 weeks- $44 \%$.

Histology of dental germs. Histological dental germ studies of offspring showed no significant differences between treated and control groups. It was observed morphological characteristics of the dental tissues surrounding bone, as well as calcium deposition in the dental mineralized matrix. In the dental germ, a pulp cellular rich loose tissue, limited by long odontoblasts was observed besides thin layers of pre-dentine matrix, mineralized dentine, a discrete layer of enamel, mineralized tissue surface and long shaped ameloblasts lying on the matrix. The surrounding trabecular bone tissue showed a regular and anastomosed pattern of regular calcium deposition.

Dental eruption in newborn rats. In the control group, teeth eruption of rats occurred at the $8^{\text {th }}$ day of birth. This time was significantly delayed in those born from mothers treated with the higher dose of verapamil (24/mg/rat/day), occurring from the $10^{\text {th }}$ to the $12^{\text {th }}$ day. The number of individuals examined were: control, 82; verapamil D1, 83; verapamil D2, 82. Results are in Table 3.

\section{Discussion}

There is a great medical, scientific and social interest in the teratogenic effect of drugs given to mothers during pregnancy. Regarding to calcium channel blockers, usually given in long term treatments, an adding interest refers to the possibility of such drugs to be a risk factor for the development of osteoporosis, a crippling bone disease that poses as a major public health problem. Although results are not always concordant, several authors have established a role of calcium blocking channels in bone cells and tissue (HERMANN-ERLEE et al., 1977; LERNER and GUSTAFSON, 1982; SIMEKOVA et al.,1987; CHAGNAC et al., 1989; ZAIDI et al., 1989, 1990; DURRIEZ et al., 1990; DATTA et al., 1990; SAMNEGARD and SJÖDÉN et al., 1992; RICHTIE et al., 1994). However, a possible influence of these agents on the teeth mineralization, either adult's or offspring's has not yet been described. This work should be considered a first approach to the subject. 
Table 3. Dental eruption in young rats born from verapamil treated mothers and control. Verapamil administered during 12 weeks** in doses of $2.4 \mathrm{mg} / \mathrm{rat} / \mathrm{day}$ (D1) and $24.0 \mathrm{mg} / \mathrm{rat} / \mathrm{day}$ (D2).

\begin{tabular}{l|c|c}
\hline \multicolumn{2}{c}{ Period of dental eruption (days) in offspring, from treated and not treated mothers } \\
\hline Control & Verapamil D1 & Verapamil D2 \\
\hline $8(\mathrm{n}=9)$ & $9(\mathrm{n}=10)$ & $10(\mathrm{n}=6)$ \\
$8(\mathrm{n}=6)$ & $8(\mathrm{n}=2)$ & $10(\mathrm{n}=9)$ \\
$8(\mathrm{n}=10)$ & $8(\mathrm{n}=11)$ & $12(\mathrm{n}=2)$ \\
$8(\mathrm{n}=6)$ & $8(\mathrm{n}=9)$ & $11(\mathrm{n}=11)$ \\
$8(\mathrm{n}=9)$ & $8(\mathrm{n}=7)$ & $11(\mathrm{n}=9)$ \\
$8(\mathrm{n}=7)$ & $8(\mathrm{n}=10)$ & $11(\mathrm{n}=7)$ \\
$8(\mathrm{n}=7)$ & $8(\mathrm{n}=11)$ & $11(\mathrm{n}=10)$ \\
$8(\mathrm{n}=9)$ & $8(\mathrm{n}=9)$ & $12(\mathrm{n}=11)$ \\
$8(\mathrm{n}=10)$ & $9(\mathrm{n}=8)$ & $10(\mathrm{n}=9)$ \\
$8(\mathrm{n}=9)$ & $8(\mathrm{n}=6)$ & $10(\mathrm{n}=8)$ \\
\hline $8.0( \pm 2.5)^{*}$ & $8.2( \pm 2.6)^{*}$ & \\
\hline
\end{tabular}

* Mean \pm SD. In brackets the number of offspring examined. ** Seven weeks before mating, 3 weeks during pregnancy, 2 weeks after birth.

Doses of verapamil used in our experiments can be considered to be adequate, because during the long term treatment the mother rats seemed to thrive and increase their body weight. No disturbed behavior was observed and no death occurred. To assure an acceptance of the drinking water with verapamil, then allowing a controlled ingestion of the drug, sucrose was added to the solution, both in the control and treated groups. The two doses of verapamil were chosen on basis of the approximate maximal doses indicated to human, that is about $7.0 \mathrm{mg} / \mathrm{kg} / \mathrm{day}$. To the rat it was chosen a "small" dose (D1) corresponding to $8.0 \mathrm{mg} / \mathrm{kg} / \mathrm{day}$ and a ten times higher dose of $80 \mathrm{mg} / \mathrm{kg} /$ day (D2). They are similar to those used by SAMNEGARD and SJÖDÉN (1992). To avoid the stress of a long term daily injection, oral route was used. Verapamil was administered for 7 weeks before and 3 weeks during pregnancy to be considered a chronically administration and along 15 days after birth, to have a condition in which a newborn is milk-fed by a treated mother. Calciumphosphate balance is essential to rat normal bone mineralization. The dietary calcium-phosphate was adequate as shown by normal growth of control and treated mother rats. They were within the range proposed by McCOY (1949) to normal development of the rat. No sign of rickets were observed.

In our experiments, the femur is indicated to be more densely mineralized in rats treated during 10 weeks but not in those treated for 12 weeks. FOX and DELLA-SANTINA (1989) and SAMNEGARD and SJÖDÉN (1992) reported in verapamil treated rats an increase in tibial bone mineralization, based in ash weight, in male rats. They reported an influence of sex since an opposite results was obtained in female, that is, bone mineralization was significantly reduced by verapamil. They attributed such differences to a possible action of verapamil in stimulating androgen secretion, absent in the female and to lower intestinal absorption of calcium in female as influenced by verapamil, a fact previously described in rats by WROBEL and MICHALSKA (1977), PENTO and JOHNSON (1983), SJÖDÉN et al. (1983). On the other hand, BROMAGE et al. (1990) described, during pregnancy, a physiological higher calcium absorption. Our results could be explained, tentatively, by the previously referred data of literature: during pregnancy, but not after delivery, a higher bone mineralization in verapamil treated mothers should corresponded to a higher calcium absorption. A decreased bone reabsorption caused by verapamil could play a role, according the suggestion of RITCHIE et al. (1994) that calcium channels antagonists may bind to the calcium channel of the osteoclasts and lock it in an open state, leading to increase intracellular calcium concentration.

Regarding to dental germ, our initial hypothesis was that verapamil could retard mineralization and tissue organization. However, they appeared not to be influenced by the drug, at least under an optical microscopy viewing. On the other hand, verapamil caused a significant delay in the eruption of the teeth, suggesting an influence on the organ organization. Maybe the histological methods used, although specific to detect mineralization, lacked sensivity for an accurate response. Histology of newly erupted teeth are currently under processing. A lower calcium blood serum concentration was observed in mothers treated with the higher doses of verapamil, in parallel with a higher mineralization of the tibial bone. However, the two processes cannot be compared, because they bear quite different physiological conditions.

Verapamil significantly decreased offspring's body weight, an effect dose related. No significant sign of toxicity and no external malformation were observed. $\mathrm{Au}$ interesting finding by VILELAGOULART et al. (1999), was that plasmatic calcium, phosphate and total protein were significantly lower in offspring of treated and 
control groups, total protein depression being over $50 \%$. In offspring born from mothers treated during 10 weeks, values were comparable between individuals from treated and control groups. However, on the $15^{\text {th }}$. day after birth, these values were significantly decreased. One can suppose a physiological balance between mother and fetus, ensuring them, during pregnancy, a normal plasmatic calcium and phosphate levels, despite of lower values in mothers, observed with higher doses.

\section{Acknowledgments}

We are grateful to Prof. José Merzel for scientific collaboration and to Mrs. Mônica O. Guimarães Figueiredo for expert technical support.

\section{REFERENCES}

AMORIM, J. B. O. Efeitos da isradipina (Lomir), agente inibidor dos canais de calcio no processo de reparo em feridas de extração dental: estudo histológico em ratos. Tese de Mestrado em Ciencias, Fac. Odont. S. J. Campos, UNESP, S. Paulo., 1995.

BROMMAGE, R.; BAXTER, D. C.; GIERKE, L. W. Vitamin-independent intestinal calcium and phosphorous absorption during reproduction. Am. J. Physiol. 259:631-638. 1990.

CHAGNAC, A.; GAZIT, D.; ZAHAVI, I.; SELA, J.; LEVI, J. Effect of verapamil on bone resorption and formation in uremic rats. Miner. Electrolyte Metab. 15: 291-294,1989.

CONOVER, W. J. Practical Nonparametric Statistics. 2nd ed., John Willey, New York, 1980.

DATTA, H. K.; MacINTIRE, I.; ZAIDI, M. Intracellular calcium in the control of osteoclast function. I. Voltage-insensivity and lack of effects of nifedipine, BAYK 8644 and diltiazem. Biochem Biophys. Res. Commun. 167:183-188, 1990.

DURRIEZ, J.; FLAUTRE, B.; BLARY, M. C.; DURRIEZ, R. Effect d'un inhibiteur calcique, le vérapamil, sur le développement des ossifications hétérotopiques. Intern. Orthopaedics, 14:415-421, 1990.

FISKE, C. H.; SUBARROW, Y. The calorimetric determination of phosphorous. J. Biol. Chem. 60:375$401,1925$.

FLECKENSTEIN, A.; KARMMERMEIER, H.; DÖRING, H. J.; FREUND, H. J. Zum wirkungsmechanismus neuartiger koronardilatoren mit glichzeitig sauertoff-einspareden MyokardEffekten, Prenylamin und Iproveratril. 2. Teil. Z. Kleislaufforsch. 56:839-853, 1967.

FLECKENSTEIN, A.; TRITTHART, H.; FLECKENSTEIN, B.; HEBST, A.; GRÜN, G. Eine neue Gruppe kompetitiver $\mathrm{Ca}^{2+}$ Antagonisten (Iproveratril, D 600, Prenylamin) mit starken Hemmeffekten die elektromeschanische Koppelung im Warmblutermyokard. Pflügers Arch. Ges. Physiol. 307:25-32, 1969.
FOX, J.; DELLA-SANTINA, C. P. Oral verapamil and calcium and vitamin $\mathrm{D}$ metabolism in rats: effect of dietary calcium. Am. J. Physiol. 257: 632-638, 1989.

GRYGORCZYC, C.; GRYGORKZYK, R.; FERRIER, J. Osteoblastic cells have L-type calcium channels. Bone Miner. 7:137-148, 1989.

HERMANN-ERLEE, M. P.; GAILLARD, G. H.; HEKKELMAN, J. W.; NIJEWEIDE, P. The effect of verapamil on the action of parathyroid hormone on embryonic bone in vitro. Eur. J. Pharmacol. 48: 51-56, 1977.

LERNER, V.; GUSTAFSON, G. T. Inhibition of 1-hydroxy-vitamin D3 stimulated bone resorption in tissue culture by the calcium antagonist verapamil. Eur. J. Clin. Invest. 12:185-190, 1982.

McCOY, R. H. Dietary requirements of the rat. In: The Rat in laboratory investigation. (Editors: Farris E. J. and Griffith J. Q. Jr.) $2^{\text {nd }}$. ed., Lippincott Co., Philadelphia, pp.68$103,1949$.

NICHOLAS, J. S. Experimental methods in rat embryo. In: The rat in laboratory investigation. (Editors Farris, J. E. and Griffith J. Q. Jr.) $2^{\text {nd }}$. Ed., Lippincott, Philadelphia, pp. 51-67, 1949.

NIES, A. S.; SPIELBERG, S. P. Principles of Therapeutics. In: GOODMAN \& GILMAN'S The Pharmacological Basis of Therapeutics. (Editors: Hardman, J. E.; Limbird, L. E.; Molinoff, P. B.; Ruddon, R. W. and Gilman A. G.) $9^{\text {th }}$ ed., McGrawHill, New York, pp. 43-62, 1996.

NOWICKY, M. C.; FOX, P. A.; TSEN, W. R. Three types of neuronal calcium channel with different calcium agonist sensivity. Nature, 316:440-443, 1985.

PEARSE, A. G. E. Histochemistry Theoretical and Applied. Little Brown, Boston, $2^{\text {nd }}$. ed., pp. 681-715, 1972.

PENTO, J. T.; JOHNSON, M. E. The influence of verapamil on calcium transport and uptake in segments of rat intestine. Pharmacology 27:343-349, 1983.

RICHTIE, C. K.; MAERKLEIN, P. B.; FITZPATRICK, L. A.. Direct effect of calcium antagonists on osteoclast function: alterations of bone resorption and intracellular calcium concentrations. Endocrinology 135:996-1003. 1994.

RICHTIE, K. C.; RICHTIE, K. C.; MAERCKLEIN, K. C.; FITZEPETRICK, A. L. Direct effect of calcium channel antagonists on osteoclast function: alterations in bone resorption and intracelular calcium concentrations. Endocrinology 135:996-1003, 1994.

SAMNEGARD, E.; SJÖDÉN, G. Verapamil increases bone volume and osteopenia in female rats but has the opposite effect in male rats. Calcif. Tissue Int. 50:524-426, 1992.

SIMEKOVA, A.; NERADILOVA, M.; BLAHOS, J.; VANA, V. The effect of verapamil and the calcium ionophore A 23187 on the calcium and mineral content of the bone. Physiol. Bohemoslov. 36:149-152, 1987.

SJÖDÉN, G.; JANARGAN, K.; DeLUCA, H. F. Inhibition of oxygen dependent calcium ion transport in the rat intestine by verapamil while phosphate ion transport is unaffected. Calcif. Tissue Int. 35 (suppl.): A32, 1983. 
VILELA-GOULART, M.G.; BASTOS-RAMOS, W.P.; ROCHA, R.F.; RANALI, J. Calcium channel blocker verapamil stimulates ovulation and induces fetal reabsorption in rats. Arch. Vet. Scienc. 3(2): 1999.

WROBEL, J.; MICHALSKA, L. The effect of verapamil on intestinal calcium transport. Eur. J. Pharmacol. 45:385-387, 1977
ZAIDI, M.; DATTA, H. K.; PATCHELL, A.; MOONGA, B.; MacINTIRE, I. "Calcium-activated" intracellular calcium elevation: a novel mechanism of osteoclast regulation. Biochem. Biophyis. Res. Commun.163:1461-1465, 1989.

ZAIDI, M.; MacINTIRE, M.; DATTA, H. Intracellular calcium in the control of osteoclast function. II. Paradoxical elevation of free calcium by verapamil. Biochem. Biophys. Res. Commun. 167:807-812, 1990. 